\title{
Black oat (Avena strigosa Schreb.) grazing or silage for small-scale dairy systems in the highlands of central Mexico. Part I. Crop and dairy cow performance
}

\author{
Jesús I. Vega-García ${ }^{1}$, Felipe López-González ${ }^{1}$, Julieta G. Estrada-Flores ${ }^{1}$, Gonzalo Flores-Calvete ${ }^{2}$, \\ Fernando Prospero-Bernal ${ }^{2}$, and Carlos M. Arriaga-Jordán ${ }^{1 *}$
}

\begin{abstract}
${ }^{1}$ Universidad Autónoma del Estado de México, Instituto de Ciencias Agropecuarias y Rurales (ICAR), Campus UAEM El Cerrillo, CP 50090 Toluca, Estado de México, México. "Corresponding author (cmarriagaj@uaemex.mx).

${ }^{2}$ Centro de Investigaciones Agrarias de Mabegondo (CIAM), Betanzos a Mesón do Vento, 15318 Mabegondo-Abegondo, La Coruña, Galicia, España.
\end{abstract}

Received: 16 March 2020; Accepted: 5 June 2020; doi:10.4067/S0718-58392020000400515

\begin{abstract}
Small-scale dairy systems are important worldwide for local and national production, and an option to overcome poverty. Effects of climate change need forage options adapted to future scenarios. This research addressed the hypothesis that black-oat (Avena strigosa Schreb.), either grazing regrowth or as first-cut silage in the dry season, is a forage option for small-scale dairy farmers in the highlands of Mexico. Part I presents performance of crop and dairy cows. There were two experiments. Treatments in Experiment 1 were restricted grazing of black-oat regrowth (BKO), black-oat with red clover (Trifolium pratense L. 'Kenland') (BKC) or a multi-species pasture (MSP) of grasses and white clover (T. repens L.) Experiment 2 evaluated inclusion of 2.5 (T1), 5.0 (T2) or 7.5 (T3) $\mathrm{kg} \mathrm{DM} \mathrm{cow}^{-1} \mathrm{~d}^{-1}$ of black-oat silage. Nine Holstein cows were used in both experiments, organized in groups of three randomly allotted to treatment in multiple $3 \times 3$ Latin squares replicated three times. Cows received $4.6 \mathrm{~kg} \mathrm{DM} \mathrm{d}^{-1}$ concentrate. There were no differences $(\mathrm{P}>0.05)$ in animal variables with mean milk yields of 10.8 and $15.2 \mathrm{~kg} \mathrm{cow}^{-1} \mathrm{~d}^{-1}, 37.7$ and $30.0 \mathrm{~g} \mathrm{~kg}^{-1}$ milkfat, 31.1 and $32.5 \mathrm{~g} \mathrm{~kg}^{-1}$ milk protein, 512.3 and $482.2 \mathrm{~kg}$ live weight, and 2.6 and 2.5 body condition score, for Experiment 1 and 2 respectively. Grazing black oat regrowth was equivalent to grazing temperate pastures, and the performance of cows was independent of the amount of black oat silage supplied. Black oat is a forage resource for small-scale dairy systems for grazing and silage.
\end{abstract}

Key words: Alternative forages, family dairying, grazing, silage.

\section{INTRODUCTION}

Small-scale dairy systems (SSDS) are important worldwide and in Mexico for their contribution to local and national milk supplies, and as an option to reduce rural poverty (Espinoza-Ortega et al., 2007). Over 88\% of cattle farms in Mexico have herds under 35 cows plus replacements, and these systems contribute up to $37 \%$ of national milk production, providing income, occupation, and avoiding migration from rural areas (Espinoza-Ortega et al., 2007).

The sustainability of SSDS requires the optimal use of home-grown forages to reduce reliance on external inputs and increase their efficiency (Morales et al., 2014; Prospero-Bernal et al., 2017); since feeding is the main component of production costs representing between 55\% and 70\% of total costs (Mwendia et al., 2017).

Grazing in the rainy season reduces feeding costs and increases profitability of farms (Prospero-Bernal et al., 2017). However, farmers face shortages during the dry season, when forage silages are quality options (Valderrama and 
Anrique, 2011; Restelatto et al., 2013; Mwendia et al., 2017), and as complement to grazing (Ruiz-Albarran et al., 2016; Prospero-Bernal et al., 2017).

In dairy systems based on grazing, it is necessary to assess the effects of pasture quality and quantity in grazing strategies, so that research has been aimed at studying factors that affect herbage growth, quality and utilization, and the productive performance of dairy cows (Morales et al., 2018).

Among these factors, possible effects of climate change may decrease forage yields due to changes in precipitation or in rainfall patterns. Therefore, there is a need to explore forage options better adapted to these possible scenarios (Thornton et al., 2009).

Small-grain cereals have rapid growth and require less water than maize, the main crop in central Mexico and in SSDS (Prospero-Bernal et al., 2017). Common oat (Avena sativa L.) is an important forage in temperate areas of the world for animal production as grazing, hay, or silage (Romero, 2000; Mwendia et al., 2017). In Mexico, common oat is widely adapted and useful for late sowing when conditions do not warrant the maize crop (Sánchez Gutiérrez et al., 2014); and has proven to be a good forage source as silage for SSDS (Celis-Alvarez et al., 2016).

However, black oat (Avena strigosa Schreb.) may be a better option, as a short cycle small-grain cereal tolerant to water deficit conditions and poor soils; prevalent in small scale systems in central Mexico, that affect feed production in terms of quantity and quality. A stable supply of forages during critical seasons or difficult conditions is required by dairy systems in other parts of the world as in Chile and in the Balkans (Morales et al., 2018; Radonjic et al., 2019).

Black oat has good feeding quality for cattle; with a high ability to regrow after cutting (Romero, 2000; Restelatto et al., 2013), and may have higher DM yields than common oat. There are few reports on the use of black oat for feeding dairy cows in Mexico, and none on its use for grazing.

The hypothesis of the work herein reported is that black oat (A. strigosa), either grazing regrowth or as first-cut silage in the dry season, is a viable forage option for milking cows in small-scale dairy farms in the central highlands of Mexico. This paper presents the results on the performance of the crop and dairy cows.

\section{MATERIALS AND METHODS}

The work followed a participatory livestock research approach (Conroy, 2005); deemed essential for the assessment of forage options for small-scale farming systems (Peters et al., 2001), as both researchers and farmers collaborate to understand a problem and develop possible technological solutions. In this context, local farmers and researchers as external facilitators jointly identify, experiment, and validate technologies, strengthening local capabilities for the improvement of their communities (Conroy, 2005).

The experiments were on the small-scale dairy farms of four brothers who manage their herds separately but jointly manage their land.

Farms were located in the central highlands of Mexico $\left(20^{\circ} 10^{\prime} \mathrm{N}, 99^{\circ} 48^{\prime} \mathrm{W}\right)$, with a sub-humid temperate climate and mean altitude of $2470 \mathrm{~m}$, a mean temperature of $14^{\circ} \mathrm{C}, 800 \mathrm{~mm}$ rainfall with summer rains between May and October and a dry season from November to mid-May (Burbano-Muñoz et al., 2018).

Experiment 1 took place in autumn 2016 (10 October to 20 November) at the end of the rainy season, and Experiment 2 took place during spring 2017 (10 April to 21 May) at the height of the dry season.

Sowing of black oat (Avena strigosa Schreb. 'Saia') was on 7 July 2016 in a 2.5 ha rain-fed plot with $120 \mathrm{~kg} \mathrm{ha}^{-1}$. Half the plot (1.25 ha) was over-sown with red clover (Trifolium pratense L. 'Kenland') at $10 \mathrm{~kg}$ seed ha ${ }^{-1}$. Fertilizations were $80 \mathrm{~N}-60 \mathrm{P}_{2} \mathrm{O}_{5}-40 \mathrm{~K} \mathrm{~kg} \mathrm{ha}{ }^{-1}$ at sowing (Salgado et al., 2010; Sánchez-Gutiérrez et al., 2014).

Ensiling of black oat (for Experiment 2) was on 12 September (67 d post-sowing), and the regrowth fertilized on 10 October with $80 \mathrm{~kg} \mathrm{~N} \mathrm{ha}^{-1}$ (for Experiment 1). At cutting, red clover had not emerged. Ensiling was in ground silos covered with a 600-caliber black plastic sheet, sealed with soil on top.

Grazed multispecies pastures, with limited irrigation in the dry season, used in both experiments were sown in 2015, with perennial ryegrass (Lolium perenne L. 'Bargala' and 'Payday'), and festulolium (Lolium perenne/L. multiflorum Lam. $\times$ Festuca pratensis Huds. 'Spring Green') at $30 \mathrm{~kg}$ seed ha ${ }^{-1}$ associated with $3 \mathrm{~kg}$ seed ha ${ }^{-1}$ of white clover (Trifolium repens L. 'Ladino'). In Experiment 1 grazing was on 1.0 ha (MSP-1), in Experiment 2, grazing was on a further 2.0 ha (MSP2), totaling 3.0 ha of multispecies pasture in Experiment 2. The target stocking rate in both experiments was 3 cows ha' ${ }^{-1}$. 


\section{Experiment 1}

The experiment followed a multiple $3 \times 3$ Latin square design replicated three times (Kaps and Lamberson, 2004; Lawal, 2014), evaluating the following three continuous grazing treatments: grazing of black oat regrowth (BKO), grazing of black oat regrowth associated with red clover (BKC), and grazing of multispecies pasture (MSP-1). Grazing was for $8 \mathrm{~h}$ $\mathrm{d}^{-1}(09: 00$ to 17:00 h), with water freely available. BKO and BKC plots were adjusted to $1.0 \mathrm{ha}$, and cows kept overnight in pens after the evening milking with no other feed provided. Each cow received additionally $4.6 \mathrm{~kg} \mathrm{DM} \mathrm{d}^{-1}$ of a commercial concentrate $(21 \% \mathrm{CP})$ as is customary practice by participating farmers. Concentrate was provided in two split meals a day at milking. Milking was twice a day by hand.

Nine multiparous Holstein cows were selected for Experiment 1. Mean pre-experimental variables were $11.4 \pm 1.86 \mathrm{~kg}$ cow $^{-1} \mathrm{~d}^{-1}$ milk yield, $226 \pm 43.2$ days in milk, $502 \pm 22.8 \mathrm{~kg}$ live weight, and $2.4 \pm 0.05$ body condition score (BCS) on a 1 to 5 scale.

The nine cows were in three groups (squares) of three cows each according to similar parity, milk yield, and live weight following Morales et al. (2018). Treatment sequences for the experiment were randomly assigned, and each cow within squares was also randomly assigned to sequence.

The experiment lasted for $42 \mathrm{~d}$ in three experimental periods of $14 \mathrm{~d}$ each, with $10 \mathrm{~d}$ for adaptation to diets, and the last $4 \mathrm{~d}$ for sampling. Experimental periods of $14 \mathrm{~d}$ are valid for feeding experiments with dairy cows when treatments do not change radically, as reported here. These are well validated by the research group at Institut National de la Recherche Agronomique (INRA)-Rennes in France, who have utilized 14 d (or shorter) experimental periods both in Latin square and in other experimental designs (Pérez-Prieto et al., 2012; Miguel et al., 2014).

Net herbage accumulation (NHA) and sward height (at the end of each experimental period) with a sliding plate grass meter followed procedures described by Plata-Reyes et al. (2018). NHA estimation was from six $0.25 \mathrm{~m}^{2}$ exclusion cages per treatment cutting to ground level with shears a $0.4 \times 0.4 \mathrm{~m}$ quadrant. Metal exclusion cages and quadrants were manufactured by hand in a local workshop, and the grass meter was made from aluminum also in a local workshop. Measurement of height of BKO and BKC was with a ruler, and the leaves:stem ratio estimated following Sánchez Gutiérrez et al. (2014) of composite samples of both BKO and BKC.

Chemical composition analyses for grazed herbage samples using the hand-plucking technique (simulating grazing) at the end of each experimental period (Morales et al., 2018), when samples of concentrate were also taken. Dry matter $(\mathrm{DM})$, organic matter $(\mathrm{OM})$, crude protein $(\mathrm{CP})$, neutral detergent fiber (NDF), acid detergent fiber (ADF), and in vitro DM digestibility (IVDMD) followed established procedures described by Celis-Alvarez et al. (2016), and estimated metabolizable energy (eME) from AFRC (1993).

\section{Experiment 2}

A multiple $3 \times 3$ Latin square design replicated three times evaluated the inclusion of three levels of black oat silage (BOS) to complement cows grazing multispecies pastures for $8 \mathrm{~h} \mathrm{~d}^{-1}$ in the dry season. Treatments were the inclusion of 2.5, 5.0, and $7.5 \mathrm{~kg}$ DM BOS $\operatorname{cow}^{-1} \mathrm{~d}^{-1}, \mathrm{~T} 1, \mathrm{~T} 2$ and T3, respectively. A control treatment was not included, since as mentioned by Condo Plaza and Pazmiño Guadalupe (2015), there is well documented evidence of the need for complementary forage in the dry season due to low herbage growth (Prospero-Bernal et al., 2017). All cows received $4.6 \mathrm{~kg} \mathrm{DM} \mathrm{d}^{-1}$ commercial concentrate. Grazing was for $8 \mathrm{~h} \mathrm{~d}^{-1}$ (09:00 to 17:00 h).

The BOS and concentrate, weighed daily for each cow, were individually provided per cow, divided in two equal meals in the overnight pen after milking following (Burbano-Muñoz et al., 2018). BOS refusals were weighed every morning, with no refusals for concentrate. Drinking water was available at all times for cows at pasture and in the overnight pens.

Similar to Experiment 1, in Experiment 2 nine Holstein cows were assigned in multiple Latin squares of three to treatment sequences. Cows in each Latin square were similar in parity, mean milk yield, and live weight. Mean preexperimental variables were $13.4 \pm 1.16 \mathrm{~kg} \mathrm{~d}^{-1}$ milk yield, $87 \pm 22.0 \mathrm{~d}$ in milk, $471 \pm 14.31 \mathrm{~kg}$ live weight and $2.5 \mathrm{BCS}$. Treatment sequences per square, and cows within square for treatment sequence, were randomized.

Cows grazed continuously 3.0 ha of pasture (MSP-1 and MSP-2) with free access between pastures for $8 \mathrm{~h} \mathrm{~d}^{-1}$ representing a stocking rate of 3 cows ha-1. Each experimental period was $14 \mathrm{~d}$.

Recording of animal and pasture variables, and chemical analyses of feeds were as in Experiment 1. Sampling of BOS for chemical composition was at different points of the silage face, and pasture herbage samples were hand plucked simulating grazing (Morales et al., 2018). Determination of $\mathrm{pH}$ was in a dilution of silage with distilled water. 
In both experiments, milking was by hand two times a day (05:30 and 18:00 h). Cows were milked by their individual owner at the stable in each farm. Recording of milk yield was with a clock spring balance (Torino-Oken, México) during the last $4 \mathrm{~d}$ of each period and refrigerated to avoid changes in chemical composition till their analyses (Radonjic et al., 2019). Milk fat, milk protein and lactose content were determined with an ultrasound analyzer (Ekomilk Bond, Ekomilk, Stara Zagora, Bulgaria) in samples of each milking, and weighted means used for analyses. Milk urea N (MUN) followed procedures from previous work of Celis-Alvarez et al. (2016).

Recording of live weight (LW) with an electronic scale (Model W310, Gallagher, Hamilton, New Zealand) was on the last four consecutive days of each experimental period, using mean LW for analyses. Body condition score (1 to 5 scale) determination was on the last day of each period.

Estimation of herbage DM intake from utilized metabolizable energy followed Baker (1982), subtracting eME from concentrate supplementation in Experiment 1, and from concentrate and BOS intake in Experiment 2, to total ME requirements of the cows to determine grazed herbage intake from eME of herbage (Morales et al., 2018). There were no concentrate refusals.

Both experiments were analyzed with ANOVA as a multiple $3 \times 3$ Latin square design replicated three times (Kaps and Lamberson, 2004; Lawal, 2014) with the following model (Burbano-Muñoz et al., 2018):

$$
\mathrm{Y}_{\mathrm{ijkl}}=\mu+\mathrm{S}_{\mathrm{i}}+\mathrm{C}_{\mathrm{j}(\mathrm{i})}+\mathrm{P}_{\mathrm{k}}+\mathrm{t}_{\mathrm{l}}+\mathrm{e}_{\mathrm{ijkl}}
$$

where $\mu$ is general mean, $\mathrm{S}$ is the effect due the $\mathrm{i}^{\text {th }}$ Latin square $(1,2,3), \mathrm{C}$ is the effect due to $\mathrm{j}^{\text {th }}$ cow $(1,2,3)$ within each square, $\mathrm{P}$ is the effect due to the $\mathrm{k}^{\text {th }}$ experimental period $(1,2,3)$, $\mathrm{t}$ is the effect due to $\mathrm{l}^{\text {th }}$ treatment $(1,2,3)$, and $\mathrm{e}$ is residual error term.

Statistical analyses of chemical composition of grazed plots in Experiment 1 was in a totally random design with the model:

$$
Y_{i j}=\mu+T_{i}+e_{i j}
$$

where $\mu$ is general mean, $\mathrm{T}$ is the effect due to the $\mathrm{i}^{\text {th }}$ treatment $(1,2,3)$, and $\mathrm{e}$ is residual error term.

This paper reports an on-farm experiment undertaken with four participating farmers who had knowledge of the objectives of the work and were duly informed at all times, and their privacy and that of their family is respected by not disclosing their names. Experimental procedures with dairy cows, and research with collaborating farmers followed accepted procedures by Universidad Autónoma del Estado de México.

\section{RESULTS}

In Experiment 1, NHA in BKC was 51\% higher than in BKO, and nearly double than MSP-1. Height in both black oat plots was similar, and compressed sward height in MSP-1 was marginally under the nominal target of $5 \mathrm{~cm}$ for continuous grazing. Herbage availability for cows was 15.7, 24.3, and $12.0 \mathrm{~kg} \mathrm{DM} \mathrm{cow}^{-1} \mathrm{~d}^{-1}$ for BKO, BKC and MSP, respectively (Table 1).

For Experiment 2, mean yield at cutting for silage of the black oat crop was $3385 \mathrm{~kg} \mathrm{DM} \mathrm{ha}^{-1}$ with no red clover present.

MSP-1 had a higher NHA than MSP-2. Mean NHA in the multispecies pastures was $20.3 \mathrm{~kg} \mathrm{DM} \mathrm{ha}^{-1} \mathrm{~d}^{-1}$, with a mean herbage availability of $6.8 \mathrm{~kg} \mathrm{DM} \mathrm{cow}^{-1} \mathrm{~d}^{-1}$.

Grazed BKO and BKC in Experiment 1 showed good quality, compared to MSP that only had a significant $(\mathrm{P}<0.05)$ higher $\mathrm{CP}$ content. In terms of IVDMD and eME, there were no differences $(\mathrm{P}>0.05)$ between the three treatments, due to the early development stage of black oat when grazed. Even though the proportion of red clover associated with black oat in the BKC treatment was low, CP content was $11 \%$ higher, but without significant differences between the two black oat pastures $(\mathrm{P}>0.05)($ Table 2$)$.

Fiber contents (NDF and ADF) were higher in the MSP in Experiment 1 (autumn) than in Experiment 2 (spring). BOS had good nutritional quality, given that ensiling was early at heading resulting its high IVDMD (723 $\left.\mathrm{g} \mathrm{kg}^{-1} \mathrm{DM}\right)$ and eME (10.7 MJ kg-1 DM). Silage $\mathrm{pH}$ was 4.2, near the value of 4.0 that indicates a good silage preservation. The leaf:stem ratio in a composite sample of the black oat crop (BKO and BKC) was $41 \%$ of leaf and $59 \%$ stem.

Table 3 shows nonsignificant differences in either experiment for any variable $(\mathrm{P}>0.05)$; and no differences $(\mathrm{P}>0.05)$ in herbage intake between BKO, BKC or MSP, or in total feed intake in Experiment 1 (Table 4).

In Experiment 2 there was a strong substitution effect with increasing BOS intake reducing MSP herbage intake from 5.7 to $2.3 \mathrm{~kg} \mathrm{DM} \mathrm{cow}^{-1}$ but with no differences $(\mathrm{P}>0.05)$ in total DM intake. There were no concentrate refusals in either experiment, and BOS refusals were highest in $\mathrm{T} 3$ with no differences between $\mathrm{T} 1$ and $\mathrm{T} 2$. 
Table 1. Net herbage accumulation (NHA) and height in Experiment 1 on grazing black oat regrowth and Experiment 2 on the inclusion in the diet of black oat silage in the performance of dairy cows.

\begin{tabular}{|c|c|c|c|c|}
\hline & \multicolumn{3}{|c|}{ Experimental periods } & \\
\hline & 1 & 2 & 3 & \\
\hline Experiment 1 & \multicolumn{3}{|c|}{ NHA (kg DM ha-1) } & Total \\
\hline BKO & 519 & 1010 & 487 & 2016 \\
\hline $\mathrm{BKC}$ & 871 & 838 & 1349 & 3058 \\
\hline \multirow[t]{2}{*}{ MSP-1 } & 420 & 676 & 420 & 1541 \\
\hline & \multicolumn{3}{|c|}{ NHA per day $\left(\mathrm{kg}\right.$ DM ha-1 $\left.\mathrm{d}^{-1}\right)$} & Media \\
\hline BKO & 37 & 72 & 34 & 47 \\
\hline BKC & 62 & 59 & 99 & 73 \\
\hline \multirow[t]{2}{*}{ MSP-1 } & 31 & 48 & 30 & 36 \\
\hline & \multicolumn{3}{|c|}{ Height (cm) } & Mean \\
\hline BKO & 27.0 & 27.3 & 18.4 & 24.2 \\
\hline BKC & 27.3 & 29.9 & 16.6 & 24.6 \\
\hline MSP-1 & 4.4 & 4.6 & 4.3 & 4.4 \\
\hline Experiment 2 & & NHA $(\mathrm{kg} \mathrm{I}$ & & Total \\
\hline MSP-1 & 124 & 403 & 586 & 1113 \\
\hline \multirow[t]{2}{*}{ MSP-2 } & 180 & 326 & 275 & 781 \\
\hline & \multicolumn{3}{|c|}{ NHA per day $\left(\mathrm{kg}\right.$ DM ha-1 $\left.\mathrm{d}^{-1}\right)$} & Media \\
\hline MSP-1 & 8 & 28 & 41 & 25 \\
\hline \multirow[t]{2}{*}{ MSP-2 } & 12 & 23 & 19 & 18 \\
\hline & \multicolumn{3}{|c|}{ Height $(\mathrm{cm})$} & Media \\
\hline MSP-1 & 5.0 & 3.8 & 4.1 & 4.3 \\
\hline MSP-2 & 3.0 & 2.6 & 2.5 & 2.7 \\
\hline
\end{tabular}

BKO: Black oat pasture; BKC: black oat with red clover; MSP: multi-species pasture.

Table 2. Chemical composition of feeds $\left(\mathrm{g} \mathrm{kg}^{-1} \mathrm{DM}\right.$, except eME and $\left.\mathrm{pH}\right)$.

\begin{tabular}{|c|c|c|c|c|c|c|}
\hline Experiment 1 & BKO & $\mathrm{BKC}$ & MSP & Mean & SEM & Concentrate \\
\hline DM & $227 \mathrm{~b}$ & $233 b$ & $189 \mathrm{a}$ & 216 & $4.79 *$ & 915 \\
\hline OM & $897 \mathrm{c}$ & $892 b$ & $878 \mathrm{a}$ & 889 & $0.30 *$ & 846 \\
\hline $\mathrm{CP}$ & $135 \mathrm{a}$ & $150 \mathrm{~b}$ & $210 \mathrm{c}$ & 165 & $9.2 *$ & 219 \\
\hline NDF & 542 & 534 & 497 & 524 & $11.4 \mathrm{~ns}$ & 244 \\
\hline ADF & 275 & 280 & 261 & 272 & $5.4 \mathrm{~ns}$ & 75 \\
\hline IVDDM & 750 & 776 & 794 & 773 & $15.6 \mathrm{~ns}$ & 811 \\
\hline eME, MJ kg-1 DM & 10.0 & 10.3 & 10.5 & 10.3 & $0.17 \mathrm{~ns}$ & 10.8 \\
\hline Experiment 2 & BOS & & MSP-1 & \multicolumn{2}{|c|}{ MSP-2 } & Concentrate \\
\hline DM & 195 & & 213 & \multicolumn{2}{|c|}{212} & 922 \\
\hline $\mathrm{OM}$ & 874 & & 894 & \multicolumn{2}{|c|}{871} & 859 \\
\hline $\mathrm{CP}$ & 94 & & 213 & \multicolumn{2}{|c|}{240} & 205 \\
\hline NDF & 586 & & 464 & \multicolumn{2}{|c|}{449} & 208 \\
\hline ADF & 380 & & 216 & \multicolumn{2}{|c|}{202} & 72 \\
\hline IVDDM & 723 & & 813 & \multicolumn{2}{|c|}{780} & 891 \\
\hline eME, MJ kg-1 DM & 9.9 & & 10.8 & \multirow{2}{*}{\multicolumn{2}{|c|}{10.2}} & 11.4 \\
\hline $\mathrm{pH}$ & 4.2 & & & & & \\
\hline
\end{tabular}


Table 3. Animal variables in Experiment 1 on grazing black oat regrowth and Experiment 2 on the inclusion in the diet of black oat silage in the performance of dairy cows.

\begin{tabular}{|c|c|c|c|c|}
\hline \multirow[b]{2}{*}{ Experiment 1} & \multicolumn{3}{|c|}{ Treatments } & \multirow[b]{2}{*}{ SEM } \\
\hline & $\mathrm{BKO}$ & $\mathrm{BKC}$ & MSP & \\
\hline Milk yield, $\mathrm{kg} \mathrm{cow}^{-1} \mathrm{~d}^{-1}$ & 10.9 & 10.9 & 10.6 & $0.49 \mathrm{~ns}$ \\
\hline Milk fat, $\mathrm{g} \mathrm{kg}^{-1}$ & 38.0 & 37.4 & 37.9 & $0.17 \mathrm{~ns}$ \\
\hline Milk protein, $\mathrm{g} \mathrm{kg}^{-1}$ & 31.2 & 31.2 & 31.1 & $0.05 \mathrm{~ns}$ \\
\hline Lactose, $\mathrm{g} \mathrm{kg}^{-1}$ & 45.0 & 46.2 & 44.8 & $0.10 \mathrm{~ns}$ \\
\hline MUN, $\mathrm{mg} \mathrm{dL}^{-1}$ & 12.1 & 12.1 & 12.9 & $1.41 \mathrm{~ns}$ \\
\hline Live weight, $\mathrm{kg}$ & 515.9 & 515.9 & 505.3 & $3.61 \mathrm{~ns}$ \\
\hline \multirow[t]{2}{*}{ Body condition score } & 2.6 & 2.7 & 2.7 & $0.06 \mathrm{~ns}$ \\
\hline & \multicolumn{3}{|c|}{ Treatments } & \\
\hline Experiment 2 & $\mathrm{~T} 1$ & $\mathrm{~T} 2$ & $\mathrm{~T} 3$ & SEM \\
\hline Milk yield, $\mathrm{kg} \mathrm{cow}^{-1} \mathrm{~d}^{-1}$ & 15.0 & 15.3 & 15.2 & $0.33 \mathrm{~ns}$ \\
\hline Milk fat, $\mathrm{g} \mathrm{kg}^{-1}$ & 29.8 & 30.1 & 29.5 & $0.05 \mathrm{~ns}$ \\
\hline Milk protein, $\mathrm{g} \mathrm{kg}^{-1}$ & 32.8 & 32.5 & 32.3 & $0.02 \mathrm{~ns}$ \\
\hline Lactose, $\mathrm{g} \mathrm{kg}^{-1}$ & 47.0 & 47.1 & 46.6 & $0.03 \mathrm{~ns}$ \\
\hline MUN, mg dL ${ }^{-1}$ & 10.4 & 10.8 & 12.5 & $0.94 \mathrm{~ns}$ \\
\hline Live weight, $\mathrm{kg}$ & 481.9 & 480.7 & 484.2 & $4.75 \mathrm{~ns}$ \\
\hline Body condition score & 2.5 & 2.4 & 2.6 & $0.05 \mathrm{~ns}$ \\
\hline
\end{tabular}

Table 4. Feed intake in Experiment 1 on grazing black oat regrowth and Experiment 2 on the inclusion in the diet of black oat silage in the performance of dairy cows.

\begin{tabular}{|c|c|c|c|c|}
\hline \multirow[b]{2}{*}{ Experiment 1} & \multicolumn{3}{|c|}{ Treatments } & \multirow[b]{2}{*}{ SEM } \\
\hline & $\mathrm{BKO}$ & $\mathrm{BKC}$ & MSP & \\
\hline & \multicolumn{3}{|c|}{$\mathrm{kg} \mathrm{DM} \mathrm{cow}^{-1} \mathrm{~d}^{-1}$} & \\
\hline Concentrate & 4.5 & 4.5 & 4.5 & \\
\hline Herbage & 6.9 & 6.4 & 6.3 & $0.31 \mathrm{~ns}$ \\
\hline \multirow[t]{2}{*}{ Total intake } & 11.4 & 10.9 & 10.9 & $0.31 \mathrm{~ns}$ \\
\hline & \multicolumn{3}{|c|}{ Treatments } & \\
\hline \multirow[t]{2}{*}{ Experiment 2} & $\mathrm{~T} 1$ & $\mathrm{~T} 2$ & $\mathrm{~T} 3$ & SEM \\
\hline & \multicolumn{3}{|c|}{$\mathrm{kg} \mathrm{DM} \operatorname{cow}^{-1} \mathrm{~d}^{-1}$} & \\
\hline Concentrate & 4.6 & 4.6 & 4.6 & \\
\hline BOS intake & 1.4 & 4.1 & 5.3 & \\
\hline BOS refusal & 1.0 & 0.8 & 2.1 & \\
\hline Herbage intake & 5.7 & 3.3 & 2.3 & $0.34 * *$ \\
\hline Total intake & 11.7 & 12.1 & 11.9 & $0.40 \mathrm{~ns}$ \\
\hline
\end{tabular}

BKO: Black oat pasture; BKC: black oat with red clover; MSP: multi-species pasture; BOS: black oat silage; T1: $2.5 \mathrm{~kg} \mathrm{DM} \mathrm{cow}^{-1} \mathrm{~d}^{-1}$ black oat silage; T2: $5.0 \mathrm{~kg} \mathrm{DM} \mathrm{cow}{ }^{-1} \mathrm{~d}^{-1}$ black oat silage; T3: $7.5 \mathrm{~kg} \mathrm{DM} \mathrm{cow}{ }^{-1} \mathrm{~d}^{-1}$ black oat silage; SEM: standard error of the mean.

**Significant $(\mathrm{P}<0.01)$; ns: nonsignificant $(\mathrm{P}>0.05)$.

\section{DISCUSSION}

\section{On-farm experiments}

Small-scale dairy systems are an important option for rural development given the increasing demand for foods of animal origin. They also contribute to the improvement of rural livelihoods by the income and employment opportunities they generate in rural and peri urban communities (Conroy, 2005; Espinoza-Ortega et al., 2007).

Conroy (2005) mentioned that there has not been much participatory research in livestock, and Peters et al. (2001) deemed that research on forage options for tropical production systems should be participatory. The advantage of on-farm 
experimentation is that these take place under the real-life situations faced by farmers (Burbano-Muñoz et al., 2018); that enable researchers to investigate problems that limit the development of these farms (Stroup et al., 1993).

The experiments took place under the conditions of the participating farmers, their labor, their herds, their land, and their management. On-farm research with small-scale farmers faces limitations like small land holdings and herds to carry out the experiments, but these are off-set by the benefits of participatory research as stated by Stroup et al. (1993).

In the context of the experiments herein reported, in Experiment 1 each treatment group of three cows grazed together on their treatment pasture. In Experiment 2 all cows jointly grazed the available pastures. Separate pastures per treatment in Experiment 2, although advisable, were unfeasible for participating farmers.

Stroup et al. (1993) and Conroy (2005) point out on the benefits of trade-offs when limitations of on-farm experiments are compared to experiments on research stations, since on-farm experiments enable a faster process for technology development and dissemination among farmers.

The use of repeated $3 \times 3$ Latin squares is a design that maximizes a limited number of experimental units (cows) as is the case in these on-farm experiments. Therefore, in the multiple $3 \times 3$ Latin squares repeated three times, simultaneous in space and time with cows nested into squares (groups), the number of observations per treatment was 9, leaving 14 degrees of freedom for the residual error term. The use of this design has proven useful for on-farm experiments (CelisAlvarez et al., 2016; Burbano-Muñoz et al., 2018; Plata-Reyes et al., 2018).

\section{Black oat and pasture variables}

The DM yields of black oat at $68 \mathrm{~d}$ post sowing for a first cut silage for Experiment 2 were promising at $3385 \mathrm{~kg} \mathrm{DM} \mathrm{ha}^{-1}$ under rain fed conditions. Once the NHA of the grazing treatments of BKO and BKC are added, with a mean of $2537 \mathrm{~kg}$ DM ha ${ }^{-1}$ in $42 \mathrm{~d}$, total yield was $5922 \mathrm{~kg} \mathrm{DM} \mathrm{ha}^{-1}$ in $110 \mathrm{~d}\left(53.8 \mathrm{~kg} \mathrm{DM} \mathrm{ha}^{-1} \mathrm{~d}^{-1}\right)$ of good quality silage and herbage. These yields are higher than those reported by Ferolla et al. (2007) in Brazil, who obtained 2317 and $1169 \mathrm{~kg} \mathrm{DM} \mathrm{ha}^{-1}$ under cutting and grazing, respectively. Yield for black oat in this work was also higher to reports by Sánchez-Gutiérrez et al. (2014) in the north-central region of Mexico at first cut (4763 $\left.\mathrm{kg} \mathrm{DM} \mathrm{ha}^{-1}\right)$ at $106 \mathrm{~d}$ post sowing.

Restelatto et al. (2013) in Brazil evaluated the response of black oat to different fertilizer levels. The highest yield of $6000 \mathrm{~kg} \mathrm{DM} \mathrm{ha}^{-1}$ was obtained with $187 \mathrm{~kg} \mathrm{~N} \mathrm{ha}^{-1}$ and six cuts when the crop was $25-30 \mathrm{~cm}$ in height, adequate for grazing. The first cut was at $58 \mathrm{~d}$ post sowing, and after $20 \mathrm{~d}$ on average for subsequent cuts. Luz et al. (2008) evaluated $\mathrm{N}$ fertilization and sprinkler irrigation on the yield of black oat with a maximum yield of $3626 \mathrm{~kg} \mathrm{DM} \mathrm{ha}^{-1}$ under irrigation and $100 \mathrm{~kg} \mathrm{~N} \mathrm{ha}^{-1}$; slightly more than the silage cut in the work herein reported not taking into account the herbage accumulated under grazing. All these reports are below yields reported by Pin et al. (2011), who reported six cuts to black oat with a maximum yield of $16755 \mathrm{~kg} \mathrm{DM} \mathrm{ha}^{-1}$ sown in autumn with a first cut at $54 \mathrm{~d}$ post sowing and a yield in that first cut of $3780 \mathrm{~kg} \mathrm{DM} \mathrm{ha}^{-1}$.

It is interesting to note a higher NHA in the grazed plot sown with black oat associated with red clover (BKC treatment) even though red clover was only $4.8 \% \mathrm{DM}$, reflecting an early positive effect of including legumes like red clover in the seed mix.

In Experiment 1, NHA of $47 \mathrm{~kg} \mathrm{DM} \mathrm{ha}^{-1} \mathrm{~d}^{-1}$ for BKO and $73.3 \mathrm{~kg} \mathrm{DM} \mathrm{ha}^{-1} \mathrm{~d}^{-1}$ for BKC were higher than reports by Macari et al. (2006), who evaluated associations of black oat with annual ryegrass under grazing. Experimental animals started grazing at $40 \mathrm{~d}$ post sowing and continuously grazed for $116 \mathrm{~d}$. These authors reported a mean NHA of 38.5 and $41.7 \mathrm{~kg} \mathrm{DM} \mathrm{ha}^{-1} \mathrm{~d}^{-1}$ for two varieties evaluated. Higher NHA for black oat under grazing was reported by Roso et al. (1999) evaluating grazed black oat associated with annual ryegrass, with an NHA of $55.6 \mathrm{~kg} \mathrm{DM} \mathrm{ha}^{-1} \mathrm{~d}^{-1}$.

Gerdes et al. (2005) evaluated black oat in a pasture mix for grazing and reported $113.9 \mathrm{~kg} \mathrm{DM} \mathrm{ha}^{-1} \mathrm{~d}^{-1}$ although black oat was associated with the tropical grass Panicum maximum, with Lolium multiflorum and Trifolium repens.

The proportion of leaf $41 \%$ is higher to reports by Sánchez-Gutiérrez et al. (2014) who reported at 106 d post sowing $24.2 \%$ of leaf, indicating a very mature black oat crop. A high proportion of leaf is an indicator of good quality of the grazed herbage since leaves are less lignified than stems.

Mean height was $21.2 \mathrm{~cm}$ for BKO and $24.6 \mathrm{~cm}$ for BKC, similar to recommendations between 22 (Romero, 2000) and $25-30 \mathrm{~cm}$ (Restelatto et al., 2013) for grazed black oat to achieve high DM yields and optimal nutritive quality. NHA of MSP at $36.7 \mathrm{~kg} \mathrm{DM} \mathrm{ha}^{-1} \mathrm{~d}^{-1}$ was similar to reports by Burbano-Muñoz et al. (2018) on the same MSP. Grass meter sward height in MSDP-1 at $4.4 \mathrm{~cm}$ was similar to reports from other work in the area (Burbano-Muñoz et al., 2018), although lower to a nominal target sward height of $5 \mathrm{~cm}$. 
$\mathrm{CP}$ content of $\mathrm{BKO}$ at 135 and $150 \mathrm{~g} \mathrm{~kg}^{-1} \mathrm{DM}$ for $\mathrm{BKC}$ cover the protein requirement for moderate and low yielding dairy cows. These are comparable to reports in the literature, although CP content may be up to $240 \mathrm{~g} \mathrm{~kg}^{-1} \mathrm{DM}$ with high $\mathrm{N}$ fertilization (160 $\mathrm{kg} \mathrm{N} \mathrm{ha}^{-1}$ ) (Salgado et al., 2010; Peres et al., 2012; Restelatto et al., 2013; Sánchez-Gutiérrez et al., 2014). BKC herbage had a higher although nonsignificant $(P>0.05)$ content of $C P$, maybe due to the contribution of red clover in the grazed plot $(4.8 \% \mathrm{DM})$. There are not many reports in the literature on black oat associated with legumes.

NDF and ADF contents were similar to other work, although higher than reported by Salgado et al. (2010) and Peres et al. (2012). Prado et al. (2003) from work on black oat reported a range between 405 and $694 \mathrm{~g} \mathrm{~kg}^{-1} \mathrm{DM}$, from 223 to $435 \mathrm{~g} \mathrm{~kg}^{-1} \mathrm{DM}$ for ADF, and from 87.4 to $210 \mathrm{~g} \mathrm{~kg}^{-1} \mathrm{DM}$ for CP. The best quality of forage in the latter study was from samples at $72 \mathrm{~d}$ post sowing while the lower quality was at $154 \mathrm{~d}$ post sowing.

Mean IVDMD values of $750 \mathrm{~g} \mathrm{~kg}^{-1} \mathrm{DM}$ for BKO and $776 \mathrm{~g} \mathrm{~kg}^{-1} \mathrm{DM}$ for BKC were slightly lower than reports by Restelatto et al. (2013) for black oat in Brazil (786 g kg $\left.{ }^{-1} \mathrm{DM}\right)$. Salgado et al. (2010) and Rocha et al. (2004) working with black oat, and Macari et al. (2006) who evaluated black oat associated to annual ryegrass reported lower digestibilities.

MSP variables in Experiment 2 showed higher CP content than other reports on those pastures. MSP were characterized by high quality herbage with high IVDMD, although low NHA and thus, low herbage available per cow.

The early cut ensured a good quality BOS, similar to reports by Carneiro et al. (2017) from black oat silage (although pre-wilted) who also observed higher NDF content than in our experiment, but similar ADF content. Leao et al. (2017) evaluated black oat silage in micro-silos over different storage times, and found higher NDF and ADF, and lower CP content than results herein reported. IVDMD in BOS was higher than other reports from ensiled black oat, as Paris et al. (2015) and Leao et al. (2017), both from work in Parana State in Brazil, demonstrating the feasibility of high quality black oat silage when cut at an early stage.

The $\mathrm{pH}$ value of 4.2 in this work is below that reported by Carneiro et al. (2017), who evaluated the effect of two pre-drying methods for black oat silage reporting $\mathrm{pH}$ values of 4.3 for the chemical method, and 4.7 for the mechanical method. On the other hand, Paris et al. (2015) reported a lower pH value (3.9) for black oat silage in full flowering, after storage for $5 \mathrm{mo}$.

Meteorological conditions during Experiment 2, at the driest part of the dry season, limited herbage growth and NHA, with only $26.5 \mathrm{~kg} \mathrm{DM} \mathrm{ha}^{-1} \mathrm{~d}^{-1}$ for MSP-1 and only $18.5 \mathrm{~kg} \mathrm{DM} \mathrm{ha}^{-1} \mathrm{~d}^{-1}$ for MSP-2. These figures are below the NHA reported by Burbano-Muñoz et al. (2018), with a NHA between 32.5 and $52.6 \mathrm{~kg} \mathrm{DM} \mathrm{ha}^{-1} \mathrm{~d}^{-1}$ in the dry season, observed results may have been due to a lower grass meter sward height (4.3 cm in MSP-1 and $2.7 \mathrm{~cm}$ in MSP-2) than sward heights reported by Burbano-Muñoz et al. (2018).

\section{Animal variables}

There were nonsignificant differences $(\mathrm{P}>0.05)$ for any of the animal variables evaluated in terms of milk yield, milk composition, live weight, and body condition score. Milk composition is subject to changes due to several factors as herd management, stage of lactation, and nutrition (Radonjic et al., 2019). In the work herein reported, milk composition parameters are within Mexican standards for raw milk; and similar to those observed by Celis-Alvarez et al. (2016) and Burbano-Muñoz et al. (2018).

Prospero-Bernal et al. (2017) documented how the implementation of grazing in these systems reduces costs and improves profitability, and therefore the economic scale of sustainability, the weak component in the sustainability of small-scale dairy systems (Prospero-Bernal et al., 2017).

Low mean milk yields $\left(10.8 \mathrm{~kg} \mathrm{cow}^{-1} \mathrm{~d}^{-1}\right)$ were due to the advanced stage of lactation of experimental cows. Yields were lower than reports in these systems by Plata-Reyes et al. (2018), who reported $14.8 \mathrm{~kg} \mathrm{cow}^{-1} \mathrm{~d}^{-1}$ from cows grazing cultivated pastures as the MSP treatment; but similar to milk yields reported by Sainz-Sánchez et al. (2017) from cows grazing native grasslands in the area.

Milk composition and MUN values were similar to reports from previous work in the study area (Sainz-Sánchez et al., 2017; Plata-Reyes et al., 2018).

Results of Experiment 1 indicate the role that grazing black oat regrowth can have in small-scale dairy systems in central Mexico as an alternative forage crop to complement pastures or other forage sources. The fact that black oat may be grazed soon after sowing is attractive to farmers. 
There were nonsignificant differences $(\mathrm{P}>0.05)$ in animal variables due to levels of BOS inclusion in Experiment 2. Milk yields at $15.2 \mathrm{~kg} \mathrm{cow}^{-1} \mathrm{~d}^{-1}$ were higher than in Experiment 1 , and near the $15.5 \mathrm{~kg} \mathrm{cow}^{-1} \mathrm{~d}^{-1}$ reported by Celis-Alvarez et al. (2016), but lower than $18.8 \mathrm{~kg} \mathrm{cow}^{-1} \mathrm{~d}^{-1}$ reported by Burbano-Muñoz et al. (2018). These two works investigated the inclusion of common oat silage in small-scale dairy systems.

\section{CONCLUSIONS}

Regrowth of black oat (Avena strigosa 'Saia') for grazing resulted in a high quality herbage, comparable to irrigated multispecies cultivated pasture, demonstrating that grown alone or in association with red clover, is an alternative feed resource for small-scale dairy systems at the start of the dry season.

Black oat silage inclusion also proved a quality forage source that may complement grazing in the peak of the dry season, with no differences between treatments. Small-scale dairy farmers may include black oat silage in their feeding strategies in the dry season, in amounts up to $7.5 \mathrm{~kg} \mathrm{DM} \mathrm{cow}^{-1} \mathrm{~d}^{-1}$, to reduce grazing pressure in their limited pasture area.

\section{ACKNOWLEDGEMENTS}

Authors express gratitude to the four farmers who participated in this experiment, whose privacy is respected by not disclosing their names. Appreciation also to Ms. María de Lourdes Maya Salazar and Ms. Laura Edith Martínez Contreras for their assistance in the laboratory. This work was undertaken thanks to funding by the Autonomous University of the State of Mexico (Universidad Autónoma del Estado de México) through grant UAEM 3676/2014/CIA, and the Mexican National Council for Science and Technology (Consejo Nacional de Ciencia y Tecnología-CONACYT) for the postgraduate grant for Jesús Israel Vega-García.

\section{REFERENCES}

AFRC. 1993. Energy and protein requirements of ruminants. Agricultural and Food Research Council. CAB International, Wallingford, UK.

Baker, R.D. 1982. Estimating herbage intake from animal performance. p. 77-93. In Leaver, J.D. (ed.) Herbage intake handbook. British Grassland Society, Maidenhead, UK.

Burbano-Muñoz, V.A., López-González, F., Estrada-Flores, J.G., Sainz-Sánchez, P.A., and Arriaga-Jordán, C.M. 2018. Oat silage for grazing dairy cows in small scale dairy Systems in the highlands of central Mexico. African Journal of Range and Forage Science 35:63-70. doi:10.2989/10220119.2018.1473493.

Carneiro, M.K., Neumann, M., Heker-Junior, J.C., Horst, E.E., Leao, G.F.M., Galbeiro, S., et al. 2017. Mechanical and chemical dehydration for pre-drying of black oat silage. Semina: Ciências Agrárias 38:981-995. doi:10.5433/1679-0359.2017v38n2p981.

Celis-Alvarez, M.D., López-González, F., Martínez-García, C.G., Estrada-Flores, J.G., and Arriaga-Jordán, C.M. 2016. Oat and ryegrass silage for small-scale dairy systems in the highlands of central Mexico. Tropical Animal Health and Production 48:1129-1134. doi:10.1007/s11250-016-1063-0.

Condo Plaza, L.A., y Pazmiño Guadalupe, J.M. 2015. Diseño experimental en el desarrollo del conocimiento científico de las ciencias agropecuarias. Tomo I. Instituto de Investigaciones, Escuela Superior Politécnica de Chimborazo, Riobamba, Ecuador.

Conroy, C. 2005. Participatory livestock research. ITDG Publishing, Bourton-on-Dunsmore, Warwickshire, UK.

Espinoza-Ortega, A., Espinosa-Ayala, E., Bastida-López, J., Castañeda-Martínez, T., and Arriaga-Jordán, C.M. 2007. Smallscale dairy farming in the highlands of central Mexico, technical, economic, and social aspects and their impact on poverty. Experimental Agriculture 43:241-256. doi:10.1017/S0014479706004613.

Ferolla, F., Vásquez, H., Da Silva, J.F., Viana, A., Domínguez, F., e Aguilar, R. 2007. Produção de matéria seca, composição da massa de forragem e relação lâmina foliar/caule + bainha de aveia-preta e triticale nos sistemas de corte e de pastejo. Revista Brasileira de Zootecnia 36:1512-1517.

Gerdes, L., Matos, H.B.D., Werner, J.C., Colozza, M.T., Santos, L.E.D., Cunha, E.A.D., et al. 2005. Características do dossel forrageiro e acúmulo de forragem em pastagem irrigada de capim-aruana exclusivo ou sobre-semeado com uma mistura de espécies forrageiras de inverno. Revista Brasileira de Zootecnia 34:1088-1097. doi:10.1590/S1516-35982005000400002.

Kaps, M., and Lamberson, W. 2004. Change-over designs. p. 294-312. In Kaps, M., and Lamberson, W. (eds.) Biostatistics for animal science. Cromwell Press, Trowbridge, UK. 
Lawal, B. 2014. Applied statistical methods in agriculture, health and life sciences. Springer, Cham, Switzerland.

Leao, G.F., Jobim, C., Neumann, M., Horst, E.H., Dos Santos, S., Venancio, B.J., et al. 2017. Nutritional composition and aerobic stability of winter cereal silage at different storage times. Acta Scientarum. Animal Sciences 39:131-136.

Luz, P.H., Herling, V.R., Braga, G.J., Nogueira Filho, J.C.M., Faria, L.A., e de Lima, C.G. 2008. Resposta da aveia preta (Avena strigosa Schreb) à irrigação por aspersão e adubação nitrogenada. Acta Scientiarum Agronomy 30:421-426.

Macari, S., Rocha, M.G.D., Restle, J., Pilau, A., Freitas, F.K.D., e Neves, F.P. 2006. Avaliação da mistura de cultivares de aveia preta (Avena strigosa Schreb) com azevém (Lolium multiflorum Lam.) sob pastejo. Ciência Rural 36:910-915.

Miguel, M.F., Ribeiro-Filho, H.M.N., De Andrade, E.A., Moraes Genro, M.T., and Delagarde, R. 2014. Pasture intake and milk production of dairy cows grazing annual ryegrass with or without corn silage supplementation. Animal Production Science 54:1810-1816. doi:10.1071/AN14382.

Morales, A., Godoy, M., Beltrán, I., Muller, A., Balocchi, O., and Pulido, R. 2018. Changes in herbage mass and time of herbage allocation modify nutritional and metabolic status of dairy cows. Chilean Journal of Agricultural Research 78:409-418. doi:10.4067/S0718-58392018000300409.

Morales, A., Grob, D., Balocchi, O., and Pulido, R. 2014. Productive and metabolic response to two levels of corn silage supplementation in grazing dairy cows in early lactation during autumn. Chilean Journal of Agricultural Research 74:205212. doi:10.4067/S0718-58392014000200012.

Mwendia, S.W., Maass, B.L., Njenga, D.G., Nyacundi, F.N., and Notenbaert, A.M.O. 2017. Evaluating oat cultivars for dairy forage production in the central Kenyan highlands. African Journal of Range and Forage Science 34:145-155. doi:10.2989/10220119.2017.1358214.

Paris, W., Zamarchi, G., Pavinato, P.S., e Martin, T.N. 2015. Qualidade da silagem de aveia preta sob efeito de estádios fenológicos, tamanhos de partícula e pré-murchamento. Revista Brasileira de Saúde e Produção Animal 16:486-498. doi:10.1590/S1519-99402015000300002.

Peres, A.A.D.C., Carvalho, A.A.B.D., Carvalho, M.I.A.B., Vasquez, H.M., Silva, J.F.C.D., Clipes, R.C., et al. 2012. Production and quality of milk from Mantiqueira dairy cows feeding on Mombasa grass pasture and receiving different sources of roughage supplementation. Revista Brasileira de Zootecnia 41:790-796.

Pérez-Prieto, L.A., Peyraud, J.L., and Delagarde, R. 2012. Does pre-grazing herbage mass really affect herbage intake and milk production of strip-grazing dairy cows? Grass and Forage Science 68:93-109. doi:10.1111/j.1365-2494.2012.00876.x.

Peters, M., Horne, P., Schmidt, A., Holman, E., Kerridge, P.C., Tarawali, S.A., et al. 2001. The role of forages in reducing poverty and degradation of natural resources in tropical production systems. Agricultural Research and Extension Network Paper Nr 117. 16 p. Overseas Development Institute (ODI), London, UK. Available at https://www.odi.org/sites/odi.org.uk/files/odi-assets/publications-opinion-files/5218.pdf (accessed June 2020).

Pin, E.A., Soares, A.B., Posenti, J.C., and Ferrazza, J.M. 2011. Forage production dynamics of winter annual grasses sown on different dates. Revista Brasileira de Zootecnia 40:509-517.

Plata-Reyes, D.A., Morales-Almaraz, E., Martínez-García, C.G., Flores-Calvete, G., López-González, F., ProsperoBernal, F., et al. 2018. Milk production and fatty acid profile of dairy cows grazing four grass species pastures during the rainy season in small-scale dairy systems in the highlands of Mexico. Tropical Animal Health and Production 50:1797-1805. doi:10.1007/s11250-018-1621-8.

Prado, I.N.D., Moreira, F.B., Cecato, U., Wada, F.Y., Oliveira, E.D, e Rego, F.C.D.A. 2003 Sistemas para crescimento e terminação de bovinos de corte a pasto: avaliação do desempenho animal e características da forragem. Revista Brasileira de Zootecnia 32:955-965.

Prospero-Bernal, F., Martínez-García, C.G., Olea-Pérez, R., López-González, F., and Arriaga-Jordán, C.M. 2017. Intensive grazing and maize silage to enhance the sustainability of small-scale dairy systems in the highlands of Mexico. Tropical Animal Health and Production 49:1537-1544. doi:10.1007/s11250-017-1360-2.

Radonjic, D., Djordjevic, N., Markovic, B., Markovic, M., Stesevic, D., and Dajic-Stevanovic, Z. 2019. Effect of phenological phase of dry grazing pasture on fatty acid composition of cows' milk. Chilean Journal of Agricultural Research 79:278-287. doi:10.4067/S0718-58392019000200278.

Restelatto, R., Pavinato, P.S., Sartor, L.R., and Paixão, S.J. 2013. Production and nutritional value of sorghum and black oat forages under nitrogen fertilization. Grass and Forage Science 69:693-704. doi:10.1111/gfs.12076.

Rocha, M.G.D., Pilau, A., Santos, D.T.D., Montagner, D.B., Freitas, F.K.D., and Pellegrini, C.B.D. 2004. Desenvolvimento de novilhas de corte submetidad a diferentes sistemas alimentares. Revista Brasileira de Zootecnia 33:2123-2131.

Romero, O. 2000. La avena como ensilage. p. 37-52. In Romero, O., y Beratto, E. (eds.) Variedades de avena y su utilización en producción animal e industrial. Boletín INIA Nr 34. Instituto de Investigaciones Agropecuarias (INIA), Temuco, Chile.

Roso, C., Restle, J., Soares, A.B., Alves Filho, D.C., e Brondani, I.L. 1999. Produção e qualidade de forragem da mistura de gramíneas anuais de estação fria sob pastejo contínuo. Revista Brasileira de Zootecnia 28:459-467.

Ruiz-Albarran, M., Balocchi, O., Wittwer, F., and Pulido, R. 2016. Milk production, grazing behavior and nutritional status of dairy cows grazing two herbage allowances during winter. Chilean Journal of Agricultural Research 76:34-39. doi:10.4067/S0718-58392016000100005. 
Sainz Sánchez, P.A., López González, F., Estrada Flores, J.G., Martínez García, C.G., and Arriaga Jordán, C.M. 2017. Effect of stocking rate and supplementation on performance of dairy cows grazing native grassland in small-scale systems in the highlands of central Mexico. Tropical Animal Health and Production 49:179-186. doi:10.1007/s11250-016-1178-3.

Salgado, P., Le Hoa, B., Trant, V.T., Vu Chi, C., Faye, B., and Lecompte, P. 2010. Identifying suitable temperate grass species and cultural practices for herbage production in the mountain regions of North Vietnam. Grass and Forage Science 65:110-120. doi:10.1111/j.1365-2494.2009.00724.x.

Sánchez Gutiérrez, R.A., Gutiérrez Bañuelos, H., Serna Pérez, A., Gutiérrez Luna, R., y Espinoza Canales, A. 2014. Producción y calidad de forraje de variedades de avena en condiciones de temporal en Zacatecas, México. Revista Mexicana de Ciencias Pecuarias 5:131-142.

Stroup, W.W., Hildebrand, P.E., and Francis, C.A. 1993. Farmer participation for more effective research in sustainable agriculture. p. 153-186. In Ragland, J., and Lai, R. (eds.) Technologies for sustainable agriculture in the tropics. Special Publication 56. American Society of Agronomy, Madison, Wisconsin, USA.

Thornton, P.K., van de Steeg, J., Notenbaert, A., and Herrero, M. 2009. The impacts of climate change on livestock and livestock systems in developing countries: a review of what we know and what we need to know. Agricultural Systems 101:113-127. doi:10.1016/j.agsy.2009.05.002.

Valderrama, L.X., and Anrique, G.R. 2011. In situ rumen degradation kinetics of high-protein forage crops in temperate climates . Chilean Journal of Agricultural Research 71:572-577. 